New Zealand Journal of Industrial Relations, 1982, 7 77-82

\title{
COMMENTARY
}

\section{Myth and reality in industrial relations: moderates, militants and social contracts}

\author{
Pat Walsh*
}

\section{Two Conferences}

Between May 4 and May 7, 1982, two Federation of Labour conferences were held. One conference took place in the nation's mass media; the other took place on the floor of the Wellington Town Hall. The differences between the two conferences were striking and instructive. A few examples should illustrate this:

- in the "media conference", the overwhelmingly important question that absorbed delegates was the campaign by "moderate" groups to wrest back control within the FOL from the "new militants"; in the "Town Hall conference" delegates spent the great majority of their time absorbed in exhaustive debate on "bread and butter" issues unemployment, inflation, the minimum living wage, Closer Economic Relations with Australia (CER), world peace, and the wage/tax trade-off.

- in the "media conference", the culmination of this campaign, and the living symbol of this intensely divided conference, was the "moderates" attempt to censure the FOL leadership for its participation in the 10th World Trade Union Congress in Cuba earlier this year; in the "Town Hall conference", fully 74 percent of votes cast supported the existing FOL policy that encourages participation in such conferences.

- in the "media conference", the FOL leadership rode roughshod over delegates, and on the last day suppressed open debate by restricting the time available for discussion of remits, and limiting debate to two speakers for and against each remit; in the "Town Hall conference" an almost day-long debate on the wage/tax trade-off, and a half-day debate on unemployment featured numerous delegates, many granted extensions of time, speaking on all aspects of the two issues; on the last day of the "Town Hall conference", delegates spent almost six hours discussing the different recommendations on remits brought down by the Remit Committees, in many cases taking the opportunity to discuss yet again issues already raised in debate on the President's and Secretary's Reports.

- in the "media conference", the third day was dull and uneventful, highlighted only by a fiery exchange on the affairs of the Wellington Boilermaker's Society; on the third day of the "Town Hall conference", delegates had been left drained by a passionate half-day debate on unemployment that culminated in a dramatic address by an unemployed worker representative that was received in an uncanny and emotion-filled silence by the 384 delegates present.

The two conferences - the "media conference" and the "Town Hall conference" proceeded side by side, sometimes touching each other, but always liable to veer off in

* Lecturer, Industrial Relations Centre, Victoria University of Wellington. 
remarkably different directions. There are several reasons for this. One of the most important of these is the nature of the media's conception and understanding of industrial relations. The media choose to characterize industrial relations as being essentially about conflict. Not only is conflict a highly marketable commodity but the stress upon it often makes easier the job of a reporter charged with the dauntingly complex task of condensing a complicated industrial issue into two columns of print or three minutes of air-time.

Very often, of course, this emphasis upon conflict is quite appropriate since most of the key issues in the union/employer relationship do involve conflict. But when carried over to the reporting of a trade union conference, this stress upon conflict is likely to be more inaccurate than accurate. At a union conference most of the delegates are on the same side most of the time. This is not to deny the importance of conflict within trade unions. Such conflict has been a major source of change, both positive and negative, in the development of the New Zealand trade union movement and there certainly was conflict at the 1982 FOL Conference, but it was of a minor nature. The minority faction never commanded the support of more than one-quarter of delegates, and even then, their conflict with the great majority of delegates was focussed on a small number of issues.

Despite this, the media searched endlessly for conflict: television cameras rolled on cue whenever a member of the minority faction approached the microphone; a "Checkpoint" radio interviewer plaintively asked her reporter - "Can we hope for any fireworks tomorrow?"; and following the conference, television's "Close-up" gave detailed and sympathetic coverage to the strategies of the minority faction. In fact, however, the great bulk of delegates' time and energies at the 1982 FOL conference was taken up with issues that expressed their united opposition to their common enemies - their employers and the government. But the dominant impression gained from the media was of a significantly and bitterly divided conference. This was a myth - a myth born of the media's quenchless preoccupation with conflict. Out of this preoccupation emerged the two conferences "media conference" and "Town Hall conference" - myth and reality in industrial relations.

\section{The Town Hall Conference}

The 1982 FOL conference will be remembered primarily for the debate over the Government's proposal for a wage/tax trade-off. This was the reality of the conference - a trade union movement giving consideration to a political and economic issue of enormous significance. The nature of this debate, and what it tells us about the New Zealand trade union movement ensures that the 1982 FOL conference will be of enduring importance for industrial relations in New Zealand.

A wage/tax trade-off is a form of incomes policy and, as such, continues the recent tradition of incomes policies in New Zealand that began with the Stabilisation of Remuneration Act in 1971. But in one vital respect, the Government's policy in this case has differed from previous incomes policies. Those policies rarely, if ever, involved any significant degree of consultation by government with trade unions and employers. Instead, they were introduced by unilateral government action. It has been argued that this lack of consultation was an important reason for their failure and that the incomes policies of the 1970s foundered on union and employer resistance. The degree of consultation involved in the proposal for a wage/tax trade-off constitutes a recognition by government that it is no longer desirable to try to enforce incomes policies unilaterally. For the first time a New Zealand government had proposed a social contract.

But overseas experience has shown that social contracts pose their own particular problems. Where they have been introduced by agreement between government and union and employer elites without any consultation with their membership, especially union membership, they have encountered major problems through this lack of membership commitment. These elite agreements have also provoked deep divisions within trade union movements through membership hostility to union leaders whom they regard as having 
sold them out. The determination of the FOL leadership to submit the Government's proposal for a social contract - the wage/tax trade-off - to its annual conference constitutes an effort to forestall these problems.

Thus, the conference debate, as much as the decision to reject the proposal, was of great significance for industrial relations in New Zealand. It represented the first active involvement by trade unions in the introduction of an incomes policy; and it represented an awareness by trade union leadership, that in the absence of membership approval, their own consent to the Government's proposal would be counter-productive. For these reasons, the conference debate and the reasons why union delegates overwhelmingly rejected the proposal warrant close scrutiny.

\section{The Debate}

The wage/tax trade-off debate occupied most of the second day of the conference. FOL economist Alf Kirk, spoke to a seventeen-page paper for more than an hour, and then answered delegate's questions. Kirk first examined the Government's proposal in isolation from other factors. He noted that in general, a trade-off based upon a higher tax-cut offered more benefits to lower-paid workers. Assuming a \$7 per week tax cut (the approximate mid-point of the two extremes of the Government's proposal) Kirk showed that 70 percent of workers would benefit, and 30 percent would lose from the Government's proposal. However, the net benefits would not be large for each individual worker. At the average wage $(\$ 14,700)$ the net weekly gain would be 84 cents. (For a $\$ 5$ tax cut the average wage-earner would gain 58 cents, while for a $\$ 10$ tax cut the weekly gain would be $\$ 1.10$.

Thus, the money-wage gain for each worker would be small, but if the wage/tax tradeoff significantly reduced inflation, as the Government claimed, then the real wage gain would be greater. However, Kirk showed that the impact of the trade-off upon inflation would be minor, and that even this minor impact is not assured. With a $\$ 7$ per week tax cut, the trade-off leads to an overall reduction in wage settlements of 4.2 percent. Using the Government Statistician's calculation that one-third of each percentage increase in inflation stems from each single percentage increase in wages, he pointed out that a wage settlement reduction of 4.2 percent will only reduce inflation by 1.4 percent. But even this modest reduction is far from assured since it depends upon the wage settlement reductions being reflected in a slower rate of price increases. There is no formal mechanism in the Government's proposal to ensure that this actually happens. A related issue, noted by Kirk, is that those who derive their income from sources other than negotiated wage agreements also benefit from the tax reduction, but make no trade-off by a reduction in income. In effect they win twice.

Kirk emphasized that the trade-off cannot be considered in isolation from other factors. The Government's proposal would reduce Government revenue by something between $\$ 300$ million and $\$ 700$ million. This reduction could lead to one of the three outcomes: (1) The Government may finance the cut in personal income tax by increased indirect taxation. This would hurt lower-paid workers who spend proportionally more of their income and would incur more sales tax. (2) The Government could finance the cuts in tax revenue by reducing its spending on health, education and welfare, and other government services that benefit workers. In this case workers are worse off because the provision of government services is reduced, and the social wage is lowered. It also increases unemployment. (3) The revenue cuts could be financed by increased government borrowing. This generates inflationary pressures that erode real wages and leave workers worse off. Thus, Kirk concluded, the trade-off is a form of "supplementary minimum prices" for employers a government subsidy on the wages they pay which is financed either out of taxes paid by workers, or by government borrowing.

Kirk went on to consider the trade-off in relation to proposals for tax reform, and to evaluate the impact of possible tax reform on the distribution of gains and losses. He 
examined the "most likely case" of tax reform, involving a raising of the income levels at which different marginal tax rates take effect. In this case, the 35 percent marginal tax rate would apply to income between $\$ 5,500$ and $\$ 16,000$, a 48 percent rate to income between $\$ 16,001$ and $\$ 22,000$, and a 55 percent rate on income between $\$ 22,001$ and $\$ 32,000$. Using again the example of a $\$ 7$ per week tax cut, the proportion of workers who would then benefit from the trade-off is reduced from 70 percent to 50 percent. In this case the average wage-earner now loses 70 cents a week. As well as this, he pointed out a further unfavourable effect. The pressure for lower marginal tax rates would be reduced because total tax paid is lower with the trade-off in effect. This would leave in place the current distribution of the tax burden which has shifted progressively onto workers in the last decade.

Kirk finished by relating these economic arguments to political and industrial considerations. He pointed out that should the conference reject the proposal, theGovernment would almost certainly enforce it by legislating for wage controls and the trade-off as proposed, and would break off union discussions with Government on wider issues, including fiscal policy. He stated that delegates must decide: (a) whether the economic costs he had outlined would in fact be incurred if the proposal was accepted; and (b) if so, whether these costs were worth incurring in order to avoid the consequences of rejection.

Kirk was followed by David Thorp, Chairman of the Combined State Unions, who read out the CSU's decision to reject the trade-off in its present form - particularly in the absence of any formal mechanism to preserve government services. In the ensuing debate there was general acceptance of Kirk's economic arguments.

By mid-afternoon a consensus had emerged that the costs of approval were unacceptable. Indeed delegates felt that they were so obviously unacceptable that the Government could not seriously have expected approval. This led them to consider whether the Government actually hoped for rejection so as to provide a stick with which to beat the unions in a possible snap election. A tentative suggestion that if this was the case, the conference should vote for conditional acceptance was however received negatively. Delegates pointed out that the proposal had to be considered on its merits, and that they could not be drawn into speculation over the Government's electoral strategy.

Debate moved to consideration of the implications of rejection. It was generally accepted that rejection would lead to legislated wage controls, including the trade-off. A consensus emerged that this would have to be tolerated as a price of rejection. Delegates argued that they could not be seen to have accepted a proposal which was so demonstrably unfair to their members. On the other hand, the injustice of wage controls could mobilize the membership into enhanced commitment and active support for the union movement's resistance to the legislation. There was also a feeling that wage controls had proven ineffective in the past, and might prove similarly ineffective again. Delegates seemed to feel that acceptance damned them to hell, while rejection damned them to purgatory. Thus, rejection offered at least the long-term hope of salvation. The Executive's motion was moved by the President, Jim Knox. It rejected the proposal and called for a campaign of action to resist the trade-off. (See appendix for full text.) The executive motion was passed almost unanimously and the wage/tax trade-off was rejected.

\section{Other Issues}

Despite the fundamental importance of the wage/tax trade-off proposal, delegates were inevitably concerned with a wide range of other issues. Not surprisingly, in view of the current economic crisis, the trade union movement showed itself to be preoccupied with fundamental economic issues. As noted earlier, delegates spent almost a half-day explicitly debating the issue of unemployment, which was also a recurring theme in other discussions. A motion that all affiliated unions should contribute one percent of their revenues to assistance for the unemployed, through their Trades Council was passed unanimously. It appeared that New Zealand's trade unions had taken to heart the costly lessons learnt in the 1930s when splits developed between the Unemployed Workers' Movement and the 
(numerically smaller) trade union movement. The conference also endorsed a remit opposing the Government's industry restructuring programme, and expressed its opposition to CER as serving the interests of monopolies and multinationals. Concern was expressed at the lack of available information about CER, and the representative from the Australian Council of Trade Unions assured delegates that the ACTU would pass on information made available to it by the Australian Government, but withheld from the FOL by the New Zealand Government. The conference again endorsed the FOL's Alternative Economic Strategy, and urged that Trades Councils and their affiliates become more actively involved in this. Other basic economic issues such as the cost of living, the minimum living wage, youth rates, and redundancy were also widely discussed.

It was predicted in some quarters that international affairs would generate considerable controversy. However, with regard to the key question of FOL attendance at World Federation of Trade Union (WFTU) conferences the right-wing faction led by Neary (North Island Electrical Workers) and Trott (Harbour Boards Workers) were in a clear minority. Trott himself had to bear a stinging attack from Meatworkers' secretary Blue Kennedy for his role in organizing the anti-union faction at Oringi. It is probable that this did not help the cause of the right-wing.

The Chile trade ban issue was resolved, with President Jim Knox being instructed by the conference to take up the question with the International Confederation of Free Trade Unions (ICFTU) and to lift the ban if this seems appropriate. It appeared that this was a face-saving compromise that could be accepted by all sides. Once it became clear that the key unions involved in enforcing the ban were opposed to its continuation, then the likelihood of such a compromise formula was high. The Polish issue received considerable attention, but again, did not create great controversy. The conference accepted the Policy Committee's recommendation to delete a reference in the Electrical Workers' remit to the Polish military being "directed" by the Soviet Union, and to withdraw a call in the Watersiders' remit for a national day of protest to support the Polish workers. The conference reaffirmed its opposition to nuclear arms and nuclear testing, and endorsed the principle of a Pacific Trade Union Forum. Delegates also condemned the 1981 Springbok Tour, and congratulated the protest organisers and participants as constituting "the largest and most representative movement of the people of this country ever seen".

Two notable concerns of the conference were with the issues of trade union education and membership mobilization. The increasing priority given to these concerns appears to reflect the new directions being brought about by the Knox/Douglas leadership. In his Presidential Address, Knox argued that: "Central to the development of the trade union movement at the present time is the need for a co-ordinated strategy of trade union education". He categorized the need to build up grassroots organization as the "most important" policy issue currently facing the trade union movement. These concerns were also prominent in the wage/tax trade-off debate, particularly in the motion which rejected the trade-off. This motion called for a general campaign of action both to resist the trade-off and to press for the minimum living wage, based upon a programme of trade union education and membership mobilization. Delegates stressed the need to explain the reasons for rejection to the membership, and to ensure that the membership was mobilized to support that rejection. It would appear that these changes, stimulated by the new leadership, are associated with a realization that New Zealand's unions can no longer shelter behind the arbitration system, but must rely upon their own resources.

There were eight candidates for four Executive positions. Despite speculation that key unions would withdraw their support for Bill Andersen (Northern Drivers), he was comfortably reelected. The other sitting candidates were also easily reelected - Ernie Ball (Engineers), Ashley Russ (Carpenters) and Wes Cameron (Meatworkers). The issue of Labour Party/trade union links was not prominent at the conference. Despite his statements criticizing the nature of the relationship, Bill Rowling was received about as warmly as a Labour Party leader could expect to be after three successive electoral defeats. Rowling raised the issue of union/party links, but this did not seem to provoke any great 
interest. It appeared that delegates were more concerned with attending to basic trade union issues, and those concerned with the party relationship seemed prepared to reserve that concern for the Labour Party conference the following week. A tub-thumping piece of traditional oratory by David Lange, attacking government policy and drawing upon the poverty and misery caused by those policies, especially in his own electorate of Mangere, aroused more enthusiasm from delegates.

\section{Conclusion}

Despite media myths, the 1982 FOL Conference revealed the existence of a considerable measure of unity within the trade union movement. Dissent was largely restricted to a minority faction led by the North Island Electrical Workers. However, it appears that they felt strongly enough about the issue of FOL links to the WFTU to persuade them to consider withdrawal from the FOL at their 1983 conference. The heated debates that occurred over a number of issues appeared to demonstrate the vitality of the union movement more than the existence of fundamental divisions. For the most part, delegates shared a common perception of the issues confronting New Zealand's trade union movement. This was that current Government policy seems systematically to shift the burden of the depression onto the shoulders of the workers. In these circumstances, trade union movements always tend to close ranks and to concentrate on fundamental economic issues in an effort to respond to these developments. This conference was no exception.

\section{Appendix}

\section{FEDERATION OF LABOUR RECOMMENDATIONS ON WAGE/TAX TRADE-OFF}

The national executive, after careful consideration of the Government's proposals for a wage/tax trade-off, recommends that they be rejected.

It is the opinion of the national executive that the proposals are not in the interest of workers, beneficiaries and superannuitants who are to suffer reductions in wages while the business, commercial and investment sectors are not confronted with any such commitment.

The proposal is not acceptable because its cost will be borne by workers in three ways. Firstly, the trade-off only affects workers not employers. Secondly, it reduces the possibility of Government action to benefit workers, and thirdly, it removes the likelihood of genuine tax reform. This difficulty arises because the proposal has been developed in isolation from other economic considerations, and for any such trade-off to be beneficial it must be linked with Government commitment to a just economic policy.

The national executive recommends to affiliates and trades councils that a campaign be entered into under the direction and control of the national executive. This campaign to focus on:

1. the harmful effects of this wage/tax trade-off;

2. the right to free bargaining and opposition to the imposition of wage controls;

3. the need for a minimum living wage;

4. the right to cost of living adjustments and access to the Arbitration Court for such cases;

5. the effects of Government's cuts and the need for genuine tax reform. 